\title{
Humpback whales within the Brazilian breeding ground: distribution and population size estimate
}

\author{
Artur Andriolo ${ }^{1,3, *}$, Paul G. Kinas ${ }^{2,3}$, Márcia H. Engel ${ }^{3}$, \\ Cristiane C. Albuquerque Martins ${ }^{3}$, Anne M. Rufino ${ }^{2}$ \\ ${ }^{1}$ Departamento de Zoologia, Instituto de Ciências Biológicas, Universidade Federal de Juiz de Fora, Campus Universitário, \\ 36036-900 Juiz de Fora, MG, Brazil \\ ${ }^{2}$ Laboratório de Estatística Ambiental, Instituto de Matemática Estatística e Fisica, Universidade Federal do Rio Grande, \\ 96200-970 Rio Grande, RS, Brazil \\ ${ }^{3}$ Instituto Baleia Jubarte, Rua Barão do Rio Branco 26, 45900-000 Caravelas, BA, Brazil
}

\begin{abstract}
The potential impact of increasing vessel traffic and coastal development has led to concerns regarding the future of the Brazilian humpback whale Megaptera novaeangliae population. Our objective was to monitor humpback whale abundance in the Brazilian coastal breeding grounds in order to provide information to support future conservation strategies for this species. To this end, a 4 yr series (2002 to 2005) of aerial surveys was implemented. Abundance was estimated using standard line-transect methods. Data were analyzed using the software DISTANCE 5.0. Perpendicular sighting data were modeled using (1) the uniform function with cosine and simple polynomial adjustments, (2) the half-normal function with cosine, and (3) the hazard-rate function with cosine and a simple polynomial series expansion. The model that best fitted the data was selected according to Akaike's Information Criterion (AIC). We estimated the population off the Brazilian coast to be 6404 $(\mathrm{CV}=0.11)$ ind. in 2005. Alternative scenarios are presented to permit the discussion of results obtained from different $g(0)$ corrections (where $g(0)$ is the probability of detecting an animal at distance 0). We confirmed what previous studies have shown, i.e. that the studied population is increasing, and it is expected that new areas will be occupied and conflicts of interests will arise. The results of this study support the Brazilian government's stance against whaling and should be used in national and international debate to help solve conflicts of interest and to find non-lethal solutions.
\end{abstract}

KEY WORDS: Megaptera novaeangliae $\cdot$ Aerial survey $\cdot$ Abundance estimate $\cdot$ Breeding ground • South Atlantic Ocean

Resale or republication not permitted without written consent of the publisher

\section{INTRODUCTION}

Humpback whales Megaptera novaeangliae occur in all major oceans of the world. In the Southern Hemisphere, they usually migrate from summer feeding grounds in the Antarctic to mating and calving grounds in tropical and subtropical regions (Dawbin 1956, Chittleborough 1965, Mackintosh 1965). Their coastal habitat has made humpback whales especially vulnerable to modern whaling methods. The species was heavily exploited in the Southern Hemisphere from both coastal stations and pelagic waters in all major ocean basins (e.g. Chittleborough 1965, Gam- bell 1973, Williamson 1975, Tønnessen \& Johnsen 1982, Best 1994). About 200000 whales were taken after 1900, causing declines of populations to small percentages of their pre-exploitation levels (e.g. Gambell 1973, Findlay 2001). The International Whaling Commission (IWC) has afforded the species virtually complete protection since 1966, and currently recognizes 7 humpback whale breeding grounds in the Southern Hemisphere (IWC 2005), with corresponding feeding areas in high-latitude Antarctic waters (Dawbin 1966, Clapham \& Mead 1999). Breeding Stock 'A' (BSA) is one of the least known and corresponds to whales wintering off Brazil. 
Current information on the distribution of humpback whales shows that the species is abundant in the Abrolhos Bank $\left(16^{\circ} 40^{\prime}\right.$ to $\left.19^{\circ} 30^{\prime} \mathrm{S}\right)$, the main breeding area for the species in the western South Atlantic Ocean (e.g. Engel 1996, Siciliano 1997, Martins et al. 2001, Andriolo et al. 2006). Zerbini et al. (2006) described the migratory corridors and summer feeding grounds around South Georgia and the South Sandwich Islands. Stevick et al. (2006) described the first match in Shag Rocks, South Georgia Island, of a humpback whale that had previously been photoidentified in the Abrolhos Bank.

The size of the population breeding in the Abrolhos Bank was estimated for 1995 to be 1634 ind. The estimate was made using an empirical-Bayes closed markrecapture model with photo-identification data (Kinas \& Bethlem 1998). Recently, abundance estimates of the population of whales available to marking within the study area were obtained from across-year markrecapture data between 1996 and 2000. A closed population, multiple-recapture model resulted in an estimate of $2393(\mathrm{CV}=0.12)$ whales. Alternatively, an open population model suggested a population increase over the study period and an estimated population size of 3871 (CV $=0.18$ ) whales in the year 2000 (Freitas et al. 2004). The first estimate of humpback whales, using line-transect methodology, was performed off northeastern Brazil from 5 to $12^{\circ} \mathrm{S}$ (Zerbini et al. 2004). The abundance for that region was estimated at 628 ind. $(\mathrm{CV}=0.31)$. The results confirm that humpback whales are regularly found in coastal waters, as far north as $5^{\circ} \mathrm{S}$ along the northeastern coast of Brazil. In addition, a whale stranded in Piauí $\left(2^{\circ} 49^{\prime} \mathrm{S}\right.$, $41^{\circ} 42^{\prime} \mathrm{W}_{\text {; }}$ Severo et al. 2004) suggests that humpback whales may be moving west along the northern coast of Brazil. Non-systematic sightings and strandings of humpback whales were reported for other coastal areas from the Fernando de Noronha Archipelago $\left(3^{\circ} \mathrm{S}\right)$ to Rio Grande do Sul (31' 38' S; Pinedo 1985, Lodi 1994, Siciliano 1997, Pizzorno et al. 1998).

Aerial surveys using fixed-wing aircraft associated with the line-transect distance sampling methodology have been extensively used to study the distribution and to estimate the abundance of mammals (Burnham et al. 1980, Guenzel 1986, 1994, Firchow et al. 1990, Johnson et al. 1991, Andriolo et al. 2001, 2005, Secchi et al. 2001). This technique can provide accurate estimates, which are corrected for animals that should have been detected using data obtained during each survey; it also provides confidence intervals and other measures to evaluate the reliability of estimates and is generally less expensive and less time consuming than traditional counts (Guenzel 1994). The line-transect technique is useful to study humpback whales because they tend to be widely distributed throughout a large area along the coast.
The potential impact of increasing coastal development has caused concern among conservationists, scientists, and managers with regard to the future of the Brazilian humpback population. Our objective was to monitor humpback whale abundance in the Brazilian coastal breeding ground in order to provide information to support future strategies for species conservation and management.

\section{MATERIALS AND METHODS}

A 4 yr series of surveys to monitor the humpback whale population was implemented at the Brazilian breeding ground. The total area covered remained the same from 2002 to 2004, but was expanded in 2005. The sighting surveys were planned to take place at the yearly peak of humpback whale abundance off the Brazilian coast, between late August and early September (Martins et al. 2001, Morete et al. 2007) A fixed-wing, bubble-window aircraft (Aerocommander) was used to survey the transect lines along the northern limit of Bahia $\left(12^{\circ} 10^{\prime} \mathrm{S}\right)$ to the southern limit of Espírito Santo $\left(20^{\circ} 42^{\prime} \mathrm{S}\right)$ in 2002 to 2004. In 2005, the area was expanded to cover the coast from $5^{\circ} \mathrm{S}$ to $24^{\circ} \mathrm{S}$.

The study area was divided into 5 independent blocks in 2002 to 2004, and further expanded (by Blocks A1, F and G) to 8 blocks in 2005. Table 1 summarizes the effort covering the sampled area in different years.

Table 1. Block division transects established in the sampled area with related effort and length considered for the abundance estimate analysis (from which Block G was excluded). The total area remained the same from 2002 to 2004 ( 5 blocks), and was expanded in 2005 (8 blocks). n m: nautical miles. See Fig. 1 for the locations of the blocks

\begin{tabular}{|lcccc|}
\hline Year & Block & $\begin{array}{c}\text { No. } \\
\text { transects }\end{array}$ & $\begin{array}{c}\text { Effort } \\
(\mathrm{n} \mathrm{m})\end{array}$ & $\begin{array}{c}\text { Area } \\
\left(\mathrm{km}^{2}\right)\end{array}$ \\
\hline $2002-2004$ & A & 29 & 511.35 & 10181.00 \\
$2002-2004$ & $\mathrm{~B}$ & 6 & 169.07 & 6858.90 \\
$2002-2004$ & $\mathrm{C}$ & 20 & 655.36 & 28215.60 \\
$2002-2004$ & $\mathrm{D}$ & 12 & 466.99 & 18134.80 \\
$2002-2004$ & E & 10 & 322.50 & 17712.50 \\
Total & & 77 & 2125.27 & 81102.80 \\
2005 & A1 & 60 & 1297.90 & 29906.00 \\
2005 & $\mathrm{~A}$ & 29 & 511.35 & 10181.00 \\
2005 & $\mathrm{~B}$ & 6 & 169.07 & 6858.90 \\
2005 & $\mathrm{C}$ & 21 & 691.15 & 28215.60 \\
2005 & $\mathrm{D}$ & 12 & 466.99 & 18134.80 \\
2005 & $\mathrm{E}$ & 10 & 322.50 & 17712.50 \\
2005 & $\mathrm{~F}$ & 25 & 939.63 & 48995.10 \\
2005 & $\mathrm{G}$ & 31 & 672.98 & 42030.7 \\
Total & & 194 & 4398.59 & 202034.6 \\
& & & & \\
\hline
\end{tabular}


Parallel transects were systematically designed $25 \mathrm{~km}$ apart to cover the area from the coast to the $500 \mathrm{~m}$ isobath (Fig. 1). Block F was expanded beyond the $500 \mathrm{~m}$ isobath in order to cover an oil exploration area. Block $\mathrm{G}$ was added to investigate the southern boundary of the breeding ground, which was set between $23^{\circ}$ and $24^{\circ} \mathrm{S}$. The parallel design of the transects avoided under- and oversampling depending on the shape of the coast. In the northern region, corresponding to Blocks A1 and A, transects were designed in a zigzag shape due to the shelf narrowness, to better cover the area and to maximize flying effort. Survey design and flights were planned using the software 'GPS Trackmaker Pro.'

Survey protocol. The aircraft flew at a height of $500 \mathrm{ft}$ (152 m) with a constant airspeed of 90 knots. Transects were flown from 07:00 to 17:00 h according to weather conditions. Planning meetings and training sessions

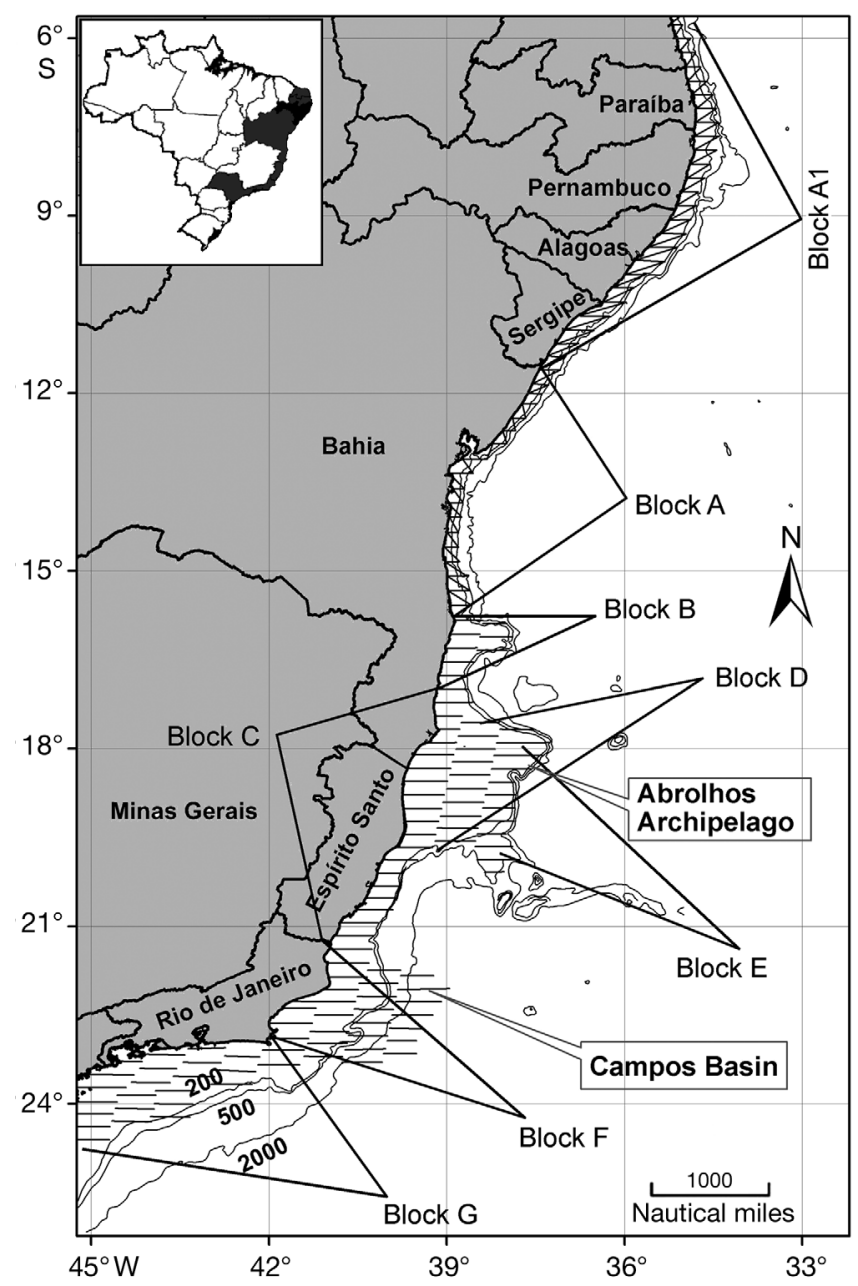

Fig. 1. Transects (black lines) established in the sampling area for aerial surveys of humpback whales at the Brazilian breeding ground. The study area was divided into blocks: the study was conducted in blocks A to E from 2002 to 2004; Blocks $\mathrm{A} 1, \mathrm{~F}$ and $\mathrm{G}$ were added in 2005. Black areas in the inset represent states where the surveys were performed were held 3 d before the survey started. Four observers participated in each flight, 3 on duty and 1 resting. They rotated approximately at 30 min intervals to match the interval between transects, when search effort was suspended to circle before starting the next transect. The 2 observers sat in front of the data recorder, searching downwards and forward constantly and less often laterally, through a bubble window on each side of the aircraft. Each observer had a hand-held clinometer, and the declination angles (where $0^{\circ}$ is at the horizon and $90^{\circ}$ is directly below the aircraft) were called when the animal or group passed perpendicularly to the plane. The sighting position was registered in a GPS receiver, and all major information was recorded on a data sheet by the data recorder. Species, group size and composition, and general comments were registered at the sighting event. All sightings were recorded following line-transect methodology (Burnham et al. 1980, Buckland et al. 1993), assuming that visibility decreases as a function of distance from the transect line.

Data analysis. Perpendicular distances were calculated from the aircraft's altitude and the declination angle to the sighting. We defined bands of increasing width, as recommended by Guenzel (1994) and Andriolo et al. (2005), which yield 8 intervals with cutpoints at distances of $0,225,494,808,1167,1569,2016,2508$, and $3000 \mathrm{~m}$ to accommodate clinometer reading errors. Truncation was applied to discard all observations beyond $3000 \mathrm{~m}$. Block $\mathrm{G}$ encompassed the southern limit at $23^{\circ} \mathrm{S}$ and was excluded from the analysis.

Abundance was estimated according to standard line-transect methods (Burnham et al. 1980, Buckland et al. 1993), and data were analyzed with the software DISTANCE 5.0 (Thomas et al. 2006). The effects of covariates were incorporated into the detection function model. This was achieved by setting the scale parameter in the model to be an exponential function of the covariates (Marques \& Buckland 2003). Thus the probability of detection becomes a multivariate function, $f(x, z)$, representing the probability of detection at perpendicular distance $x$ and covariates $z\left(z_{i}=z_{1 i}, \ldots, z_{q i}\right.$ where $q$ is the maximum number of covariates), associated with each detected object $i(i=1, \ldots, n)$. Using either a half-normal or hazard-rate detection function, the covariates were incorporated via the scale term, $\sigma$,

$$
\sigma=\exp \left(\beta_{0}+\sum_{j=1}^{q} \beta_{j} z_{i j}\right)
$$

where $\beta_{0}$ and $\beta_{j}(j=1, \ldots, q)$ are parameters to be estimated. With this formulation, it is assumed that the covariates may affect the rate at which detection decreases as a function of distance, but without changing the shape of the detection function.

A stepwise forward selection procedure was used (starting with a model containing perpendicular dis- 
tances only) to decide, based on a minimum Akaike's Information Criterion (AIC), which covariates to include in the model. We considered the following covariates: time of day, transect direction, observer, sighting side (left/right), swimming direction, cue type, geographic stratum, sea state (Beaufort), visibility, pod size, day of year, depth, glare, and cloud cover.

Each bootstrap resample was made up by sampling with replacement a number of line transects equal to that used in the original data set. The best fit model was chosen using the selected covariates (geographic stratum and sea state) and the density estimated by stratum for the selected model, hazard-rate (Eq. 2) with cosine series (Eq. 3). The same procedure was repeated for the other 99 resamples. In the end, based on the 100 iterations, a table with the bootstrap estimates of coefficients of variation and confidence intervals was produced:

$$
f(x)=k_{1} \cdot\left\{1-\exp \left[-\left(\frac{x}{\sigma(z)}\right)^{-b}\right]\right\}
$$

where $k_{1}$ is a normalization constant.

$$
\begin{gathered}
\sum_{j=1}^{q} a_{j} \cos \left(\frac{j \pi y}{w}\right) \\
f(x)=\frac{g(x)}{\mu} \\
\hat{N}=\frac{n A \bar{s}}{2 L \hat{\mu}}
\end{gathered}
$$

where the parameters are as follows - $a$ : surveyed area; $w$ : truncation point; $L$ : total line length; $A$ : size of study area, containing $N$ objects; $\mu$ : half-width of the strip; $\hat{\mu}$ : estimated half-width; $\hat{N}$ : estimated population size; n: sample size; $s$ : size of a cluster of objects; $y$ : perpendicular distance $x$ of a detected object, and $g(x)$ is the detection function.

A pooled abundance estimate for each year was calculated as the sum over the estimates for blocks and the corresponding standard error as the square root of the corresponding sum over squared standard errors. Due to insufficient data to fit a separate detection function for each stratum, we fit a global model, but using stratum (blocks) as covariates. Group size was also estimated across all blocks. Density and encounter rate were estimated by stratum (and by years). Variance was estimated from bootstrap resampling of the data, with 100 iterations.

Scenarios of detection probability. Since the detection probability is not equal to 1 in aerial surveys, we propose 3 possible scenarios of correction:

(1) N1: We estimated the probability of detecting a humpback whale at distance 0 following the approach of Barlow et al. (1988), as reported by Andriolo et al. (2006):

$$
g(0)=\frac{s+t}{s+d}
$$

where $s$ is the average time a humpback whale is at the surface; $d$ is the average time a humpback whale is submerged; and $t$ is the time window during which the humpback whale is within the visual range of an observer.

The mean time during which a humpback whale was within the visual range of an observer $(t)$ was estimated at $34 \mathrm{~s}( \pm 7.5 \mathrm{~s}, 95 \%$ confidence limits $)$. This measurement was made by directly recording the duration of visibility of any object at the surface of the sea on the trackline. The estimate for $g(0)$ as a correction factor resulted in a value of $0.67( \pm 0.15)$.

The IWC Scientific Committee (IWC 2006) recommended that for an assessment to be conducted, the $g(0)$ of 0.67 estimated by Andriolo et al. (2006) should be used.

(2) $\mathrm{N} 2=\mathrm{N} 1 \times(0.67) /(0.43)$. In this approach, we used $g(0)=0.43$ obtained from Kinas et al. (2006), calculated as the quotient of the population size estimate from distance sampling assuming $g(0)=1$ and an independent population size estimate based on mark-recapture methods.

(3) $\mathrm{N} 3=\mathrm{N} 1 \times(0.67) /(0.25)$. Here we used $g(0)=0.25$ obtained from Paxton et al. (2006), calculated as the quotient of the estimated number of pods from the aerial survey to the estimated number of pods from the land-based survey.

The estimate $g(0)$ and its standard error, $\operatorname{SE}(g(0))$, were both included in DISTANCE, which then incorporated them into the final variance estimate of abundance, according to the delta method (Buckland et. al. 1993, their Eq. 3.3).

\section{RESULTS}

The flights were scheduled on days with clear visibility of the sea surface, when cloud cover ranged from 0 to $100 \%$. The sea state varied, although most of the time $(92 \%)$ it remained between 1 and 5 (Beaufort scale). The total numbers of humpback whale sightings and individuals observed on effort and considered in the analysis are summarized in Table 2.

Table 2. Megaptera novaeangliae. Number of humpback whale sightings, total number of individuals, and number of sightings that included 1 calf ('Calves') for different monitoring years along the Brazilian coast

\begin{tabular}{|cccc|}
\hline Year & Sightings & Individuals & Calves \\
\hline 2002 & 178 & 271 & 18 \\
2003 & 211 & 378 & 29 \\
2004 & 264 & 414 & 19 \\
2005 & 334 & 539 & 32 \\
\hline
\end{tabular}



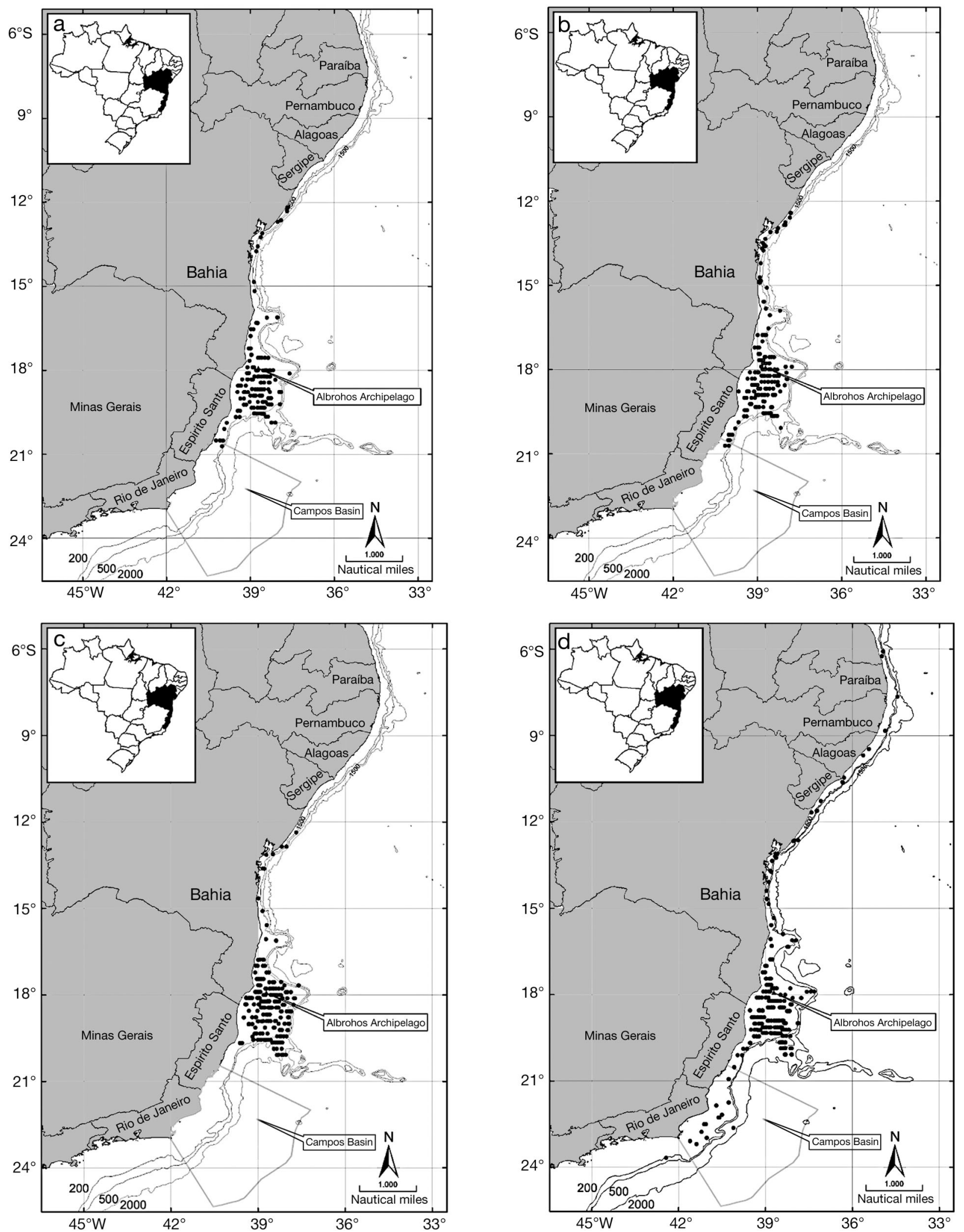

Fig. 2. Megaptera novaeangliae. General distribution of humpback whales in (a) 2002, (b) 2003, (c) 2004, and (d) 2005. (•) Sighting of a humpback whale; the area in which most dots are concentrated corresponds to the Abrolhos Bank. Black areas in the insets represent states where the surveys were performed 
Table 3. Megaptera novaeangliae. Humpback whale density estimates (ind. $\mathrm{km}^{-2}$ ) under Scenario N1 (see 'Materials and methods' for details) and encounter rates in the different areas of the Brazilian breeding ground during 2002 to 2005 . See Fig. 1 for the locations of the blocks. DS: estimate of density of clusters (no. of clusters $\mathrm{km}^{-2}$ ); D: estimate of density of animals (no. of animals $\mathrm{km}^{-2}$ ); $\mathrm{n} / \mathrm{L}$ : encounter rate (no. of sightings per total line length); CV: coefficient of variation; CI: confidence interval

\begin{tabular}{|c|c|c|c|c|c|c|c|c|c|c|}
\hline \multirow{2}{*}{$\frac{\text { Year }}{2002}$} & \multirow{2}{*}{$\frac{\text { Block }}{\text { A }}$} & \multirow{2}{*}{$\begin{array}{c}\text { Density } \\
\text { DS }\end{array}$} & \multirow{2}{*}{$\begin{array}{l}\text { Estimate } \\
0.007175\end{array}$} & \multirow{2}{*}{$\begin{array}{l}\text { \% CV } \\
33.97\end{array}$} & \multicolumn{2}{|c|}{$-95 \% \mathrm{CI}-$} & \multirow{2}{*}{$\begin{array}{c}\mathrm{n} / \mathrm{L} \\
0.0235\end{array}$} & \multirow{2}{*}{$\frac{\% \mathrm{CV}}{33}$} & \multicolumn{2}{|c|}{$95 \% \mathrm{CI}$} \\
\hline & & & & & 0.003704 & 0.013896 & & & 0.0121 & 0.0453 \\
\hline & & $\mathrm{D}$ & 0.01168 & 34 & 0.006028 & 0.022632 & & & & \\
\hline & $\mathrm{B}$ & DS & 0.006873 & 57.41 & 0.001898 & 0.024896 & 0.0237 & 62.55 & 0.0054 & 0.1036 \\
\hline & & $\mathrm{D}$ & 0.011201 & 57.5 & 0.003088 & 0.040634 & & & & \\
\hline & $\mathrm{C}$ & DS & 0.020218 & 16.25 & 0.014712 & 0.027784 & 0.0687 & 13.41 & 0.0519 & 0.0908 \\
\hline & & $\mathrm{D}$ & 0.032908 & 16.22 & 0.023961 & 0.045195 & & & & \\
\hline & $\mathrm{D}$ & DS & 0.060025 & 24.44 & 0.036953 & 0.097502 & 0.2099 & 22.28 & 0.1293 & 0.3407 \\
\hline & & $\mathrm{D}$ & 0.097714 & 24.52 & 0.060065 & 0.15896 & & & & \\
\hline & $\mathrm{E}$ & DS & 0.017329 & 25.17 & 0.0104 & 0.028874 & 0.0589 & 27.64 & 0.0319 & 0.1089 \\
\hline & & $\mathrm{D}$ & 0.028217 & 25.33 & 0.016885 & 0.047155 & & & & \\
\hline \multirow[t]{10}{*}{2003} & $\mathrm{~A}$ & DS & 0.015917 & 21.15 & 0.010519 & 0.024087 & 0.0548 & 21.86 & 0.0352 & 0.0852 \\
\hline & & $\mathrm{D}$ & 0.02592 & 21.38 & 0.017054 & 0.039396 & & & & \\
\hline & B & DS & 0.005587 & 37.15 & 0.002413 & 0.012938 & 0.0183 & 47.88 & 0.0057 & 0.0588 \\
\hline & & $\mathrm{D}$ & 0.009106 & 37.59 & 0.003897 & 0.021275 & & & & \\
\hline & $\mathrm{C}$ & DS & 0.028517 & 17.01 & 0.020437 & 0.039793 & 0.0977 & 15.63 & 0.0706 & 0.1352 \\
\hline & & $\mathrm{D}$ & 0.046409 & 16.9 & 0.033325 & 0.06463 & & & & \\
\hline & D & DS & 0.048804 & 20.36 & 0.03263 & 0.072996 & 0.1735 & 18.89 & 0.1149 & 0.2619 \\
\hline & & $\mathrm{D}$ & 0.07947 & 20.5 & 0.052992 & 0.11918 & & & & \\
\hline & $\mathrm{E}$ & DS & 0.020286 & 51.75 & 0.007014 & 0.058677 & 0.0682 & 58.11 & 0.0201 & 0.2311 \\
\hline & & $\mathrm{D}$ & 0.03299 & 51.73 & 0.01141 & 0.095383 & & & & \\
\hline \multirow{10}{*}{2004} & A & DS & 0.005956 & 34.9 & 0.003014 & 0.01177 & 0.0196 & 39.3 & 0.0090 & 0.0425 \\
\hline & & $\mathrm{D}$ & 0.009689 & 34.67 & 0.004925 & 0.019063 & & & & \\
\hline & B & DS & 0.003907 & 51.22 & 0.001213 & 0.012583 & 0.0120 & 65.5 & 0.0026 & 0.0557 \\
\hline & & $\mathrm{D}$ & 0.006355 & 51.02 & 0.001982 & 0.020373 & & & & \\
\hline & $\mathrm{C}$ & DS & 0.026084 & 26.08 & 0.01561 & 0.043586 & 0.0900 & 25.96 & 0.0528 & 0.1536 \\
\hline & & $\mathrm{D}$ & 0.042483 & 26.22 & 0.025358 & 0.071173 & & & & \\
\hline & D & DS & 0.081066 & 22.33 & 0.052068 & 0.12622 & 0.2805 & 20.9 & 0.1780 & 0.4422 \\
\hline & & $\mathrm{D}$ & 0.13198 & 22.36 & 0.084717 & 0.20561 & & & & \\
\hline & $\mathrm{E}$ & DS & 0.056171 & 18.05 & 0.039251 & 0.080384 & 0.1892 & 18.1 & 0.1260 & 0.2839 \\
\hline & & $\mathrm{D}$ & 0.091425 & 18.03 & 0.063923 & 0.13076 & & & & \\
\hline \multirow[t]{14}{*}{2005} & A1 & DS & 0.003025 & 31.96 & 0.001633 & 0.005604 & 0.0332 & 25.16 & 0.0200 & 0.0552 \\
\hline & & $\mathrm{D}$ & 0.004929 & 32.17 & 0.00265 & 0.009167 & & & & \\
\hline & $\mathrm{A}$ & DS & 0.009664 & 21.79 & 0.0063 & 0.014823 & 0.0100 & 31.04 & 0.0055 & 0.0184 \\
\hline & & $\mathrm{D}$ & 0.015729 & 21.77 & 0.010258 & 0.024119 & & & & \\
\hline & B & DS & 0.010126 & 19.14 & 0.006852 & 0.014963 & 0.0358 & 22.02 & 0.0210 & 0.0610 \\
\hline & & $\mathrm{D}$ & 0.016487 & 19.34 & 0.011114 & 0.024458 & & & & \\
\hline & $\mathrm{C}$ & DS & 0.044242 & 19.6 & 0.03011 & 0.065006 & 0.1480 & 18.91 & 0.1000 & 0.2191 \\
\hline & & $\mathrm{D}$ & 0.072002 & 19.58 & 0.049031 & 0.10573 & & & & \\
\hline & D & DS & 0.084243 & 20.42 & 0.056143 & 0.12641 & 0.2898 & 20.06 & 0.1862 & 0.4510 \\
\hline & & $\mathrm{D}$ & 0.1372 & 20.76 & 0.090844 & 0.20722 & & & & \\
\hline & $\mathrm{E}$ & DS & 0.040926 & 28.28 & 0.023321 & 0.071821 & 0.1455 & 22.49 & 0.0880 & 0.2405 \\
\hline & & $\mathrm{D}$ & 0.066676 & 28.52 & 0.03782 & 0.11755 & & & & \\
\hline & F & DS & 0.003569 & 32.02 & 0.001915 & 0.006652 & 0.0128 & 26.33 & 0.0075 & 0.0218 \\
\hline & & $\mathrm{D}$ & 0.005805 & 31.75 & 0.00313 & 0.010766 & & & & \\
\hline
\end{tabular}

\section{Distribution}

Whales were not uniformly distributed within the survey area. A clear concentration of groups was observed over the Abrolhos Bank (Fig. 2). The survey of Block G in 2005 was essential to investigate the southern boundary of the breeding ground. The south- ern limit of the breeding ground was confirmed at $23^{\circ} \mathrm{S}$, corresponding to the Arraial do Cabo area in the state of Rio de Janeiro. We observed that Block D had the highest density, and variation among years was detected. Humpback whales were registered at Block $F$ between the coast line and the oil platforms at Campos Basin, an important oil exploitation area. 


\section{Group size and composition}

Group size of humpback whales ranged from 1 to 7 . The average group size was 1.628 (95\% CI $=1.58-$ 1.68; $\mathrm{CV}=1.68)$. Calves accounted for 7.2 to $13.7 \%$ of the total humpback whale groups sighted in different years (Table 2).

\section{Abundance}

The model that fit the perpendicular distance data, based on the AIC criterion, was the hazard-rate with cosine adjustment. In total, 2 covariates were included in the model: geographic stratum and sea state. Fig. 3 presents the distribution of perpendicular distances and fit of the detection function. The estimated detection function was $f(0)=0.73483 \times 10^{-3}\left(\mathrm{SE}=0.20695 \times 10^{-4}\right.$; $\mathrm{CV}=2.67 \% ; 95 \% \mathrm{CI}=0.73483 \times 10^{-3}-0.81608^{-3}$ ).

Scenario N1 is presented with details for estimated density and encounter rate of each block per year in Table 3, and the estimated abundances are given in Table 4. Pooled abundance was estimated to be $6404(\mathrm{CV}=0.11)$ for 2005. The estimated abundances for alternative Scenarios N2 and N3 are presented in Table 5.

\section{DISCUSSION}

\section{Distribution}

Our data indicate that humpback whales are not uniformly distributed in coastal waters off Brazil. The estimated density varied among blocks (Table 3, Fig. 2). The Abrolhos Bank was the preferred area of concentration; this falls mainly within Block D, which has been recog-

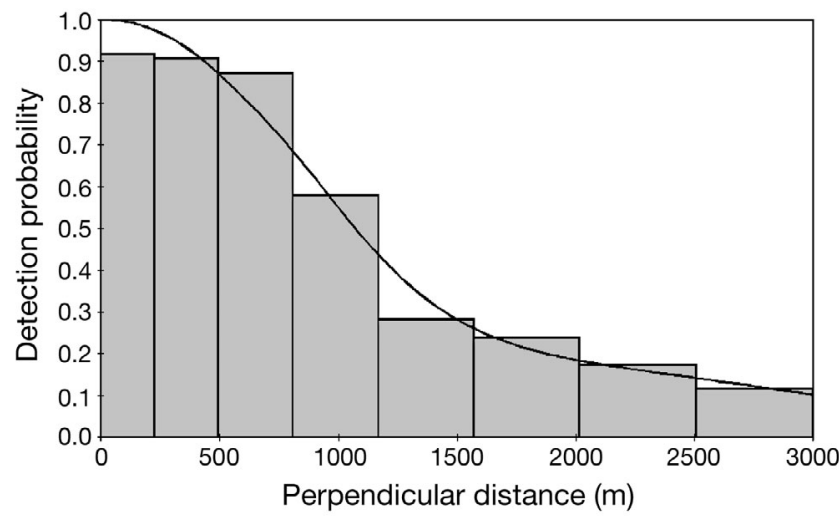

Fig. 3. Megaptera novaeangliae. Perpendicular distances and fitted detection function based on 964 sightings of humpback whales in the Brazilian breeding ground (see Fig. 1 for locations)
Table 4. Megaptera novaeangliae. Humpback whale abundance estimates under Scenario N1 (see 'Materials and methods' for details) in different areas of the Brazilian breeding ground from 2002 to 2005, and pooled estimates for different years and the actual population size. See Fig. 1 for the locations of the blocks. CV: coefficient of variation; CI: confidence interval

\begin{tabular}{|c|c|c|c|c|c|}
\hline \multirow{2}{*}{$\frac{\text { Year }}{2002}$} & \multirow{2}{*}{$\frac{\text { Block }}{\mathrm{A}}$} & \multirow{2}{*}{$\begin{array}{r}\text { Estimate } \\
118.92\end{array}$} & \multirow{2}{*}{$\begin{array}{r}\text { \% CV } \\
33.97\end{array}$} & \multicolumn{2}{|c|}{$95 \%$ CI } \\
\hline & & & & 61 & 230 \\
\hline & B & 76.85 & 57.49 & 21 & 279 \\
\hline & $\mathrm{C}$ & 928.55 & 16.22 & 676 & 1275 \\
\hline & $\mathrm{D}$ & 1772.1 & 24.52 & 1089 & 2883 \\
\hline & E & 499.79 & 25.33 & 299 & 835 \\
\hline Pooled & & 3396.21 & 14.15 & 2562 & 4501 \\
\hline \multirow[t]{5}{*}{2003} & $\mathrm{~A}$ & 263.93 & 21.37 & 174 & 401 \\
\hline & B & 62.44 & 37.58 & 27 & 146 \\
\hline & $\mathrm{C}$ & 1309.4 & 16.9 & 940 & 1824 \\
\hline & D & 1441.2 & 20.5 & 961 & 2161 \\
\hline & $\mathrm{E}$ & 584.35 & 51.72 & 202 & 1689 \\
\hline Pooled & & 3661.32 & 13.14 & 2819 & 4756 \\
\hline \multirow[t]{5}{*}{2004} & A & 98.65 & 34.68 & 50 & 194 \\
\hline & B & 43.57 & 50.92 & 14 & 139 \\
\hline & C & 1198.7 & 26.22 & 716 & 2008 \\
\hline & D & 2393.4 & 22.36 & 1536 & 3729 \\
\hline & E & 1619.3 & 18.03 & 1132 & 2316 \\
\hline Pooled & & 5353.62 & 12.83 & 4146 & 6913 \\
\hline \multirow[t]{8}{*}{2005} & A1 & 147.38 & 32.23 & 79 & 274 \\
\hline & $\mathrm{A}$ & 160.16 & 21.75 & 104 & 245 \\
\hline & B & 113.12 & 19.34 & 76 & 168 \\
\hline & $\mathrm{C}$ & 2030.6 & 19.57 & 1384 & 2983 \\
\hline & D & 2488.2 & 20.76 & 1647 & 3758 \\
\hline & $\mathrm{E}$ & 1181 & 28.52 & 670 & 2082 \\
\hline & F & 284.4 & 31.75 & 153 & 527 \\
\hline & $A, B, C, D, E$ & 5973.08 & 12.3 & 4675 & 7632 \\
\hline Pooled & & 6404.86 & 11.58 & 5084 & 8068 \\
\hline
\end{tabular}

Table 5. Alternative scenarios (N2 and N3) of humpback whale abundance at the Brazilian breeding ground in 2005 . See 'Materials and methods' for details

\begin{tabular}{|lccc|}
\hline \multirow{2}{*}{ Scenario } & Estimate & \multicolumn{2}{c|}{$95 \% \mathrm{CI}$} \\
\hline N2 & 9978.32 & 7921.58 & 12571.07 \\
N3 & 17162.72 & 13625.12 & 21622.24 \\
\hline
\end{tabular}

nized as a major calving/nursing area (Martins et al. 2001). A low-density area was observed approximately between parallels $13^{\circ} 30^{\prime} \mathrm{S}$ and $16^{\circ} 30^{\prime} \mathrm{S}$. This is the first estimate covering the whole known breeding area of whales wintering off Brazil (BSA).

Non-systematic sightings and strandings of humpback whales have been reported for other areas of the coast from the Fernando de Noronha Archipelago $\left(3^{\circ} \mathrm{S}\right)$ to Rio Grande do Sul (3138' S; Pinedo 1985, Lodi 1994, Siciliano 1997, Pizzorno et al. 1998). To date, the southern limit of the coastal distribution has been discussed based on strandings only. The aerial survey 
conducted in Block $\mathrm{G}$ was the first systematic effort to confirm the southern limit with respect to the distribution of animals on the continental shelf. This observation is supported by individual tracks documenting the beginning of the migration route (Zerbini et al. 2006), in which no animals were registered swimming southward following the coast south of the Arraial do Cabo/ Cabo Frio area in Rio de Janeiro $\left(23^{\circ} \mathrm{S}\right)$.

\section{Abundance}

The assumption of no movement prior to detection is not met when whales respond negatively (move away from the observer) or positively (approach the observer) before detection. Evasive movements and positive responses result in under- and overestimation of abundance, respectively. We did not notice an evident response of the animals related to the aircraft before sighting. Some sightings occurred when the animals were on the trackline, staying at the surface until the plane had passed.

Using an empirical Bayes closed mark-recapture model, Kinas \& Bethlem (1998) estimated the population to be about 1600 ind. $(\mathrm{SD}=155.16)$ for 1995 in the Abrolhos Bank based on photo-identification data for the area of main occurrence of humpback whales off the Brazilian coast (northern parts of Blocks C and D). Revised estimates based on data collected between 1996 and 2000 and using a variety of models have given population sizes around 3000 ind. (Freitas et al. 2004). For both of these studies, data were collected within a fraction of the known stock range for this population.

The first aerial survey, performed in 2001 (Andriolo et al. 2006), estimated the population at 2229 (CV = 0.31). Line-transect methodology to estimate humpback whale numbers was first implemented on a vessel platform off northeastern Brazil in 1999 and 2000 (Zerbini et al. 2004). The abundance of whales in the covered region (5 to $12^{\circ} \mathrm{S}$ ) was estimated at 628 ind. $(\mathrm{CV}=0.31,95 \% \mathrm{CI}=366-1091)$. The vessel platform provides good control of the $g(0)=1$ assumption because of low speed. In contrast, airplanes confer other advantages, such as size of the area covered per unit of time. This can result in more sightings, allowing for a better fit of the detection curve. Furthermore, this method could give a more detailed picture of the spatial distribution.

A weakness of aerial surveys lies in the whales' detectability on the trackline. The assumption that all animals on the trackline are detected, $g(0)=1$, is not appropriate for aerial surveys of humpback whales, since animals are not visible if they are not close enough to the surface. A true value of $g(0)<1$, when ignored, leads to visibility bias (Marsh \& Sinclair 1989), resulting in an underestimated population size. A study developed to calculate the detection probability of harbor porpoises from aerial surveys (Laake et al. 1997) discussed the visibility problem for this species. In comparison, humpback whales are very conspicuous, which facilitates their detection but does not eliminate the problem completely. A visibility bias for marine mammals occurs whenever animals are not close enough to the surface to be seen (availability bias) or when animals are visible but missed for a variety of other reasons such as sun glare or observer fatigue (perception bias). To minimize perception bias, observers were trained previously to improve their ability to collect distance data, and they routinely switched positions during the flight.

Andriolo et al. (2006) proposed a correction factor calculated from land-based data collected at the Abrolhos Archipelago, which we used in Scenario N1. Aside from the restrictive conditions under which this estimate was obtained (mostly females in the proximity of Abrolhos Bank) and the unlikely direct relation to the aerial survey, the Southern Hemisphere Humpback Workshop (IWC 2006) agreed that the uncorrected aerial survey estimate, corrected using the Barlow method (Andriolo et al. 2006), provides the best estimate abundance for 2005 . To facilitate comparison, the same estimate of $g(0)=0.67$ was calculated and used here, as the reduced aircraft speed made little difference to the $g(0)$. However, further improvement of this estimate is urgently needed and is presently under investigation. Preliminary results presented here as Scenario N2 indicate that the current $g(0)$ might be biased upward. Under Scenario N1, we estimated the humpback whale population off the Brazilian coast to be $6404(\mathrm{CV}=0.11$ ) ind. in 2005, which is considered the most up-to-date estimate of humpback population size for the Brazilian breeding ground. The most recent estimate of abundance should be used as an input parameter in the assessment models, as recommended in the Report of the Southern Hemisphere Humpback Workshop (IWC 2006).

Scenarios N2 (based on Kinas et al. 2006) and N3 (based on Paxton et al. 2006) both estimate $g(0)$ using calibration as their rational. In Scenario N2 calibration is based on the comparison of population size estimates from the line-transect technique (assuming $g(0)=1$ ) with the estimate from mark-recapture, while Scenario N3 uses the estimated number of pods from aerial and land-based surveys. In both cases, the 2 estimates are generated using different methods, have different assumptions and strengths, and may not be estimating the same population, although Scenario N3 is a better controlled setting than Scenario N2.

Based on the above discussion, all 3 scenarios must be interpreted with care. Aside from an ideal and 
specifically designed field experiment for estimation of $g(0)$, a carefully conducted simulation study under Scenario N2 might be the most promising alternative to obtain a reliable estimate for $g(0)$ and consequently of the effective population size. While substantial uncertainties about $g(0)$ remain, we think that, based on a precautionary approach, the more conservative estimate under Scenario N1 would be preferable.

We suggest that aerial surveys, following distance sampling methodology, should be applied routinely as a tool for monitoring humpback whales over time. Once adequate and standardized protocols have been established, this methodology can be used to describe population trends. A consistent data collection protocol also permits analyses of spatial variation. These analyses can be performed with an unknown correction factor $g(0)$, as long as this factor can be assumed to be constant across estimates.

\section{Conservation}

Assuming Scenario N1, our results possibly underestimated the total number of animals in this population. Applying the precautionary principle, underestimation is acceptable to avoid strategies that could negatively affect the population. However, we must continue to provide quality information to permit plan elaboration and decision strategies for whale conservation and social/economic development.

Given evidence that the studied population is increasing, it is expected that new areas will become occupied by whales. The original population depletion occurred largely before the boom in coastal activities (e.g. hydrocarbons, boat traffic, and artisanal fishing). As these activities continued to develop, they occupied space that was available as a result of low whale population density. Consequently, it is expected that conflicts will arise as the whale population increases.

Abrolhos Bank, the principal breeding ground, was carefully monitored by the government due to its importance for conservation of marine biodiversity in Brazil (Marchioro et al. 2005). In 2003, the Brazilian Environmental Agency (IBAMA), in compliance with its legal responsibility, prohibited the realization of seismic surveys on the coast of Bahia and Espírito Santo, including Abrolhos Bank, during the humpback whale breeding season (Engel et al. 2004). This prohibition was based on the distribution of the species and the potential impact that seismic activity could have on its reproductive cycle. In this sense, continued dialogue between government, research institutions, and oil companies is essential.

The outcome of international discussions on the return of whaling in the future is uncertain. The results of our study support national and international debate in agreement with the Brazilian government position against whaling, where possible conflicts of interest must be discussed and managed to establish non-lethal solutions. Recent publications (Stevick et al. 2006, Zerbini et al. 2006, in press a) confirmed one of the possible feeding grounds of the Brazilian humpback whale population near the South Georgia and South Sandwich Islands in the Antarctic convergence. The coincidental reduction of the humpback whale population in Brazilian waters with the reduction of whaling close to south Georgia provided additional evidence for a migratory connection between whales wintering off Brazil and summering off South Georgia. Whaling off South Georgia began in 1904, but by 1915 , the population had already been depleted (e.g. Tønnessen \& Johnsen 1982, Findlay 2001).

Even considering that the BSA humpback whale population is recovering (Zerbini et al. 2004, in press b, Ward et al. in press) and is reoccupying historical areas, the total number of animals is still smaller than the population size prior to whaling (Zerbini et al. 2004, in press b, Rossi-Santos et al. 2008). By registering the status and dynamics of the humpback whale population off the Brazilian coast, our study can help identify new areas for whale watching and provide valuable information to evaluate the need for new protected areas.

Many documents have focused on the vulnerable and threatened status of humpback whales (e.g. IBAMA 2001, Baillie et al. 2004, IWC 2005). The successful protection of marine mammals is directly related to the compromises of individual countries in developing their capacity for establishing priorities and strategies for a conservation plan, with technical and scientific support from national and international organizations.

Acknowledgements. We thank A. Azevedo, B. L. Bastos, C. Baracho, C. Petta, G. Vianna, I. B. Moreno, J. L. Pizzorno, L. Wedekin, T. Bisi, L. P. Juliano, L. Dalla-Rosa, L. Pacheco, M. Rossi, M. Rollo, M. Marcondes, S. Más-Rosa, and Y. F. Cunha, and the pilots César, Yshida, Marcelo, A. Masulo, F. Moura, J. Coura, and J. Sibelino. We also thank S. Moreira for providing the maps. We received logistic support from Abrolhos Turismo, Iga Táxi Aéreo Ltda, and TWO/Jade Taxi Aéreo Ltda. This study was financially supported by Aracruz Celulose and Cia. de Navegação Norsul. The official sponsor of the Instituto Baleia Jubarte is Petrobras S.A. Finally, we thank C. Bethlem, who is responsible for the start of this cooperation. M. Marcondes and the IWC Scientific Committee offered important suggestions on earlier drafts of the manuscript.

\section{LITERATURE CITED}

Andriolo A, Piovezan U, Paranhos da Costa MJR, Duarte JMB (2001) Line-transect sampling method used to evaluate the impact of a flooding dam on marsh deer (Blastocerus dichotomus) population in the Paraná River, Brazil. Deer Spec Group Newsl 16:1-2 
Andriolo A, Piovezan U, Costa MJRP, Laake J, Duarte JMB (2005) Aerial line transect survey to estimate abundance of marsh deer (Blastocerus dichotomus) (Illiger, 1815). Braz Arch Biol Technol 48:807-814

Andriolo A, Martins CCA, Engel MH, Pizzorno JL, Más-Rosa S, Freitas AC, Morete ME, Kinas PG (2006) The first aerial survey of humpback whales (Megaptera novaeangliae) to estimate abundance in the breeding ground off Brazil (Breeding Stock A). J Cetacean Res Manag 8:307-311

Baillie JEM, Hilton-Taylor C, Stuart SN (eds) (2004) IUCN Red List of Threatened Species. A global species assessment. IUCN-SSC. http://data.iucn.org/dbtw-wpd/edocs/ RL-2004-001.pdf

Barlow JC, Oliver W, Jackson TD, Taylor BL (1988) Harbor porpoise, Phocoena phocoena, abundance estimation for California, Oregon and Washington: II. Aerial surveys. Fish Bull 86:433-444

Best PB (1994) A review of the catch statistics for modern whaling in Southern Africa, 1908-1930. Rep Int Whaling Comm 44:467-485

Buckland ST, Anderson DR, Burnham KP, Laake JL (eds) (1993) Distance sampling: estimating abundance of biological populations. Chapman \& Hall, London

Burnham KP, Anderson DR, Laake JL (1980) Estimation of density from line transect sampling of biological populations. Wildl Monogr 72:1-202

Chittleborough RG (1965) Dynamics of two populations of humpback whale, Megaptera novaeangliae (Borowski). Aust J Mar Freshw Res 16:33-128

Clapham P, Mead JG (1999) Megaptera novaeangliae. Mamm Species 604:1-9

Dawbin WH (1956) The migrations of humpback whales which pass the New Zealand coast. Trans R Soc N Z 84: 147-196

Dawbin WH (1966) The seasonal migratory cycle of humpback whales. In: Norris KS (ed) Whales, dolphins and porpoises. University of California Press, Berkeley, CA, p 145-170

Engel M (1996) Comportamento reprodutivo da baleia jubarte (Megaptera novaeangliae) em Abrolhos. An Etolog 14:275-284

Engel ME, Marcondes MCC, Martins CCA, Luna FO, Lima RP, Campos A (2004) Are seismic surveys responsible for cetacean strandings? An unusual mortality of adult humpback whales in Abrolhos Bank, northeastern coast of Brazil. Paper SC/56/E28 presented to the IWC Scientific Committee, Sorrento

Findlay KP (2001) A review of humpback whale catches by modern whaling operations in the Southern Hemisphere. Mem Queensl Mus 47:411-420

Firchow KM, Vaughan MR, Mytton WR (1990) Comparison of aerial survey techniques for pronghorns. Wildl Soc Bull $18: 18-23$

Freitas AC, Kinas PG, Martins CCA, Engel MC (2004) Abundance of humpback whales on the Abrolhos bank wintering ground, Brazil. J Cetacean Res Manag 6:225-230

Gambell R (1973) Sustainable yields: how whales survive. In: Calders $N$ (ed) Nature in the round. Weidenfeld and Nicolson, London, p 193-202

Guenzel RJ (1986) Pronghorn ecology in southcentral Wyoming. MS thesis, University of Wyoming, Laramie, WY

Guenzel RJ (1994) Adapting new techniques to population management: Wyoming's pronghorn experience. Trans $\mathrm{N}$ Am Wildl Nat Resour Conf 59:189-200

IBAMA (Instituto Brasileiro do Meio Ambiente e dos Recursos Naturais Renováveis) (2001) Mamíferos aquáticos do Brasil: Plano de Ação. Vers II, 2nd edn. IBAMA, Brasília
IWC (International Whaling Commission) (2005) Report of the Scientific Committee, Annex H. Report of the sub-committee on other Southern Hemisphere whale stocks, Appendix 7. Report of the intercessional group: work required to complete assessment of Southern Hemisphere humpback whales. J Cetacean Res Manag 6 (Suppl): 259-267

IWC (International Whaling Commission) (2006) Report of the Southern Hemisphere Humpback Workshop SC/58/Rep 5, Hobart. Available at http://iwcoffice.org/_documents/sci_ com/workshops/WorkshopReports/SC-58-Rep5.pdf

Johnson BK, Lindsey FG, Guenzel RJ (1991) Use of aerial line transect surveys to estimate pronghorn populations in Wyoming. Wildl Soc Bull 19:315-321

Kinas PG, Bethlem CP (1998) Empirical Bayes abundance estimation of a closed population using mark recapture data, with application to humpback whales, Megaptera novaeangliae, in Abrolhos, Brazil. Rep Int Whaling Comm 48:447-450

Kinas PG, Andriolo A, Engel MH (2006) Integrating photoidentification and aerial surveys to estimate $g(0)$ for humpback whales (Megaptera novaeangliae) in the Brazilian breeding ground. SC/AO6/HW24. Available at http://iwcoffice.org/

Laake JL, Calambokidi J, Osmek S, Rugh D (1997) Probability of detecting harbor porpoise form aerial surveys: estimating $g(0)$. J Wildl Manag 61:63-75

Lodi L (1994) Ocorrências de baleias-jubarte, Megaptera novaeangliae, no Arquipélago de Fernando de Noronha, incluindo um resumo de registros de capturas no Nordeste do Brasil. Biotemas 7:116-123

Mackintosh NA (1965) The stocks of whales. Fishing News Books, London

Marchioro GB, Nunes MA, Dutra GF, de Moura RL, Pereira PGDP (2005) Avaliação dos impactos da exploração e produção de hidrocarbonetos no Banco dos Abrolhos e adjacências. Megadiversidade 1:225-310

Marques FFC, Buckland ST (2003) Incorporating covariates into standard line transect analyses. Biometrics 59: 924-935

Marsh H, Sinclair DF (1989) Correcting for visibility bias in strip transect aerial surveys of aquatic fauna. J Wildl Manag 53:1017-1024

Martins CCA, Morete ME, Engel MH, Freitas AC, Secchi ER, Kinas PG (2001) Aspects of habitat use patterns of humpback whales in the Abrolhos Bank, Brazil, breeding ground. Mem Queensl Mus 47:563-570

> Morete M, Bisi T, Rosso S (2007) Temporal pattern of humpback whale (Megaptera novaeangliae) group structure around Abrolhos Archipelago breeding region, Bahia, Brazil. J Mar Biol Assoc UK 87:87-92

Paxton CGM, Banister JL, Hedley SL (2006) Group IV humpback whales: their status from aerial and land based surveys off Western Australia, 2005. SC/AO6/HW3. Available at http://iwcoffice.org/

Pinedo MC (1985) A note on a stranding of the humpback whale on the southern coast of Brazil. Sci Rep Whale Res Inst 36:165-168

Pizzorno JLA, Laílson-Brito JL, Dorneles PR, Azevedo AF, Gurgel IMGN (1998) Review of strandings and additional information on humpback whales, Megaptera novaeangliae, in Rio de Janeiro, southeastern Brazilian coast (1981-1997). Rep Int Whaling Comm 48:443-446

Rossi-Santos M, Neto ES, Baracho CG, Cipolotti SR, Marcovaldi E, Engel MH (2008) Occurrence and distribution of humpback whales (Megaptera novaeangliae) on the north coast of the State of Bahia, Brazil, 2000-2006. ICES J Mar Sci 65:667-673 
Secchi ER, Ott PH, Crespo EA, Kinas PG, Pedraza SN, Bordino P (2001) A first estimate of franciscana (Pontoporia blainvillei) abundance off southern Brazil. J Cetacean Res Manag 3:95-100

Severo MM, Barragana M, Costa AF, Marinho ACC, Tannús RM (2004) Encalhe de uma baleia jubarte (Megaptera novaeangliae) na Praia de Pedra do Sal em Parnaíba-PI. Abstracts of the 3rd Encontro Nacional de Pesquisa e Conservação de Mamíferos Aquáticos, Organization Committee, Haparica-BA

Siciliano S (1997) Características da população de baleiasjubarte (Megaptera novaeangliae) da costa brasileira, com especial referência aos Bancos de Abrolhos. MS thesis, Universidade Federal Rural do Rio de Janeiro, Rio de Janeiro

Stevick PT, Godoy LP, McOsker M, Engel MH, Allen J (2006) Movement of a humpback whale from Abrolhos Bank, Brazil to South Georgia. J Cetacean Res Manag 8:297-300

Thomas L, Laake JL, Strindberg S, Marques FFC and others (2006) Distance 5.0. Research Unit for Wildlife Population Assessment, University of St. Andrews. Available at: www.ruwpa.st-and.ac.uk/distance/

Tønnessen JN, Johnsen AO (1982) The history of modern whaling. C Horst \& Co, London

Editorial responsibility: Jason Matthiopoulos, St. Andrews, UK
Ward E, Zerbini AN, Kinas PG, Engel MH, Andriolo A (in press) Estimates of population growth rates of humpback whales (Megaptera novaeangliae) in the wintering grounds off the coast of Brazil (Breeding Stock A). J Cetacean Res Manag

Williamson GR (1975) Minke whales off Brazil. Sci Rep Whale Res Inst 27:37-59

Zerbini AN, Andriolo A, da Rocha JM, Simões-Lopes PC and others (2004) Winter distribution and abundance of humpback whales (Megaptera novaeangliae) off northeastern Brazil. J Cetacean Res Manag 6:101-107

Zerbini AN, Andriolo A, Heide-Jørgensen MA, Pizzorno JL and others (2006) Satellite-monitored movements of humpback whales Megaptera novaeangliae in the Southwest Atlantic Ocean. Mar Ecol Prog Ser 313:295-304

Zerbini AN, Andriolo A, Heide-Jørgensen MA, Moreira S, and others (in press a) Migration and feeding destinations of humpback whales (Megaptera novaeangliae) in the western South Atlantic Ocean. J Cetacean Res Manag

Zerbini AN, Ward E, Engel ME, Andriolo A, Kinas PG (in press b) A Bayesian assessment of the conservation status of humpback whales (Megaptera novaeangliae) in the Western South Atlantic Ocean (Breeding Stock A). J Cetacean Res Manag

Submitted: April 28, 2008; Accepted: March 19, 2010

Proofs received from author(s): May 10, 2010 